\title{
HUBUNGAN EKSPRESI ESTROGEN RECEPTOR DENGAN SKOR GLEASON, DERAJAT DIFERENSIASI, DAN PROGNOSTIC GRADE GROUP PADA ADENOKARSINOMA PROSTAT
}

\author{
Kiki Ulfaningtyas ${ }^{* \bowtie}$, Eviana Norahmawati*, Kenty Wantri Anita*, \\ Harun Al Rasyid**, Taufiq Nur Budaya ${ }^{* * *}$
}

\begin{abstract}
Abstrak
Kanker prostat yang didominasi oleh adenokarsinoma prostat adalah salah satu keganasan yang sering didapatkan pada laki-laki. Studi terkini menyebutkan bahwa estrogen receptor berhubungan dengan kanker prostat. namun masih didapatkan kontroversi hubungan reseptor ini dengan kanker prostat dan prognosis kanker prostat. Sejauh ini, di Indonesia belum ada penelitian yang dilakukan untuk mencari hubungan ER dengan prognosis pasien kanker prostat. Penelitian ini bertujuan untuk membuktikan adanya hubungan antara ekspresi ER dengan skor Gleason, derajat diferensiasi, dan prognostic grade group pasien adenokarsinoma prostat. Desain penelitian adalah observasional analitik, menggunakan 31 sampel adenokarsinoma prostat berdasarkan perhitungan statistik. Ekspresi ER diukur pada kelompok spesimen jaringan adenokarsinoma prostat, yang kemudian dilakukan uji korelasi Spearman terhadap skor Gleason, derajat diferensiasi serta prognostic grade group (PGG). Pada penelitian ini didapatkan nilai $p>0,05$ pada uji korelasi spearman antara ekspresi reseptor estrogen terhadap skor Gleason $(p=0,601)$, derajat diferensiasi $(p=0,754)$ dan prognostic grade group $(p=0,596)$ pada adenokarsinoma prostat. Hasil penelitian juga menunjukkan kecenderungan rerata ekspresi reseptor estrogen pada kelompok poorly differentiated adenokarsinoma prostat lebih tinggi dibandingkan kelompok moderately differentiated. Namun, pada prognostic grade group terdapat kecenderungan rerata ekspresi reseptor estrogen meningkat pada PGG yang lebih tinggi. Kesimpulannya, tidak didapatkan korelasi yang bermakna antara ekspresi reseptor estrogen dengan skor Gleason, derajat diferensiasi, dan prognostic grade group pada adenokarsinoma prostat. Disarankan untuk menentukan prognosis kanker prostat dari berbagai aspek, tidak hanya dari skor Gleason, derajat diferensiasi, dan prognostic grade group, tetapi juga mempertimbangkan stadium TNM dan kadar prostate spesific antigen (PSA).
\end{abstract}

Kata kunci: adenokarsinoma prostat, derajat diferensiasi, estrogen receptor, prognostic grade group, skor Gleason

\section{CORRELATION BETWEEN ESTROGEN RECEPTOR EXPRESSION AND GLEASON SCORES, DEGREE OF DIFFERENTIATION, PROGNOSTIC GRADE GROUP ON PROSTATE ADENOCARCINOMA}

\begin{abstract}
Prostate cancer, mostly prostate adenocarcinoma, is one of the most common malignancies in men. Recent study showed that estrogen receptors had correlation to prostate cancer. Unfortunately, the corellation between these receptors and prostate cancer and its prognosis remains controversy. So far, in Indonesia there has been no study to find the relationship between ER and the prognosis of prostate. This research was to prove the relationship between ER expression and Gleason score, degree of differentiation, and prognostic grade group of prostate adenocarcinoma patients. The study design was analytic observational that using 31 samples of prostate adenocarcinoma based on statistical calculations. ER expression was measured in prostate tissue specimens from prostate adenocarcinoma patients. Gleason scores, degree of differentiation and prognostic grade group (PGG) of each specimen were also measured. Spearman correlation test showed correlation between estrogen receptor expression and Gleason score $(p=0.601)$, degree of differentiation $(p=0.754)$ and PGG $(p=0.596)$ in prostate adenocarcinoma were not significant $(p>0.05)$. It was found that the average ER expression in the poorly differentiated prostate adenocarcinoma group was slightly higher than ER expression in the moderately differentiated group. Moreover, the higher average estrogen receptor expression, the higher the level of PGG. It can be concluded that there was no significant correlation between estrogen receptor expression and Gleason score, degree of differentiation, and prognostic grade group in prostate adenocarcinoma. It is recommended to determine the prognosis of prostate cancer from the other aspect, such asTNM stage and prostate specific antigen levels.
\end{abstract}

Keywords: degree of differentiation, estrogen receptor, Gleason score, prognostic grade group, prostate adenocarcinoma 
* Department Patologi Anatomi, Fakultas Kedokteran, Universitas Brawijaya-RSUD Dr. Saiful Anwar Malang

* Department IImu Kesehatan Masyarakat, Fakultas Kedokteran, Universitas Brawijaya-RSUD Dr. Saiful Anwar Malang

${ }^{* * \star}$ Department Urologi, Fakultas Kedokteran, Universitas Brawijaya-RSUD Dr. Saiful Anwar Malang

凶E-mail: drkikityas@gmail.com

\section{Pendahuluan}

Kanker prostat merupakan salah satu kanker tersering di dunia. ${ }^{1}$ Data Internasional WHO terbaru tahun 2020, menyebutkan bahwa kanker prostat menduduki peringkat keempat kanker terbanyak di dunia dan kedua pada pria dengan jumlah sekitar 1,2 juta kasus baru. Menurut data Globocan 2018, sementara di Indonesia kanker prostat merupakan kanker tersering kelima dengan 11.361 kasus baru. ${ }^{2}$ Pada Riskesdas tahun 2013, disebutkan prevalensi kanker prostat di Indonesia sebesar 0,2 kasus per 1000 penduduk, dengan prevalensi terbanyak ter-dapat pada provinsi DI Yogyakarta, Bali, Sulawesi Utara dan Sulawesi Selatan, dengan prevalensi masingmasing sebesar 0,5 kasus per 1000 penduduk. $^{3}$ Menurut data Badan Registrasi Kanker tahun 2014, di Malang tumor prostat menduduki urutan ketiga tumor primer tersering pada laki-laki.4,5

Menurut WHO 2020, Kanker ini menjadi penyebab kematian akibat kanker di urutan kedelapan, dari sepuluh penyebab kematian tertinggi di dunia. ${ }^{2}$ Sedangkan sesuai data GLOBOCAN 2018, tercatat 5007 orang Indonesia meninggal karena kanker ini. ${ }^{2}$ Data di Indonesia menunjukkan bahwa median survival adalah 101 bulan dan 85 bulan masing-masing untuk penderita yang mendapat tindakan prostatektomi radikal dan external beam radical therapy (EBRT). Angka survival 5 tahun adalah $68,4 \%$ dan $69,2 \%$, masing-masing untuk penderita dengan pengobatan prostatektomi radikal dan EBRT. ${ }^{6}$

Adenokarsinoma prostat adalah karsinoma invasif yang terdiri dari sel-sel epitel prostat neoplastik dengan diferensiasi sekretorik tersusun dalam pola histo- morfologik yang bervariasi, yaitu kelenjar, cords, sel-sel tunggal dan lembaran-lembaran. Pada adenokarsinoma prostat tidak didapatkan sel-sel basal.1,7

Ekspresi estrogen receptor, yang terdiri dari $E R a$ dan $E R \beta$, berhubungan dengan kejadian kanker prostat baik pada hewan coba maupun manusia. ERa meningkatkan risiko kanker prostat, sedangkan ER $\beta$ bersifat protektif. Ekspresi ERa meningkatkan risiko prognosis yang buruk dan kematian pasien kanker prostat, sedangkan ekspresi ERß berhubungan negatif dengan peningkatan prostate spesific antigen (PSA), marker yang meningkat pada kanker prostat. ${ }^{8}$ Hasil yang berbeda disebutkan bahwa ER $\beta$ meningkat ekspresinya pada pasien kanker prostat dan berhubungan dengan tingkat grup prognostik berdasarkan skor Gleason. ${ }^{9}$

Secara prinsip peran ERa dan ER $\beta$ pada kanker prostat mirip dengan pada kanker yang lain, ERa bertindak sebagai onkogen dan ER $\beta$ bertindak sebagai tumor suppressor. Peran keduanya pada kanker prostat berpengaruh secara langsung atau tidak langsung pada proses tumorigenesis, proliferasi sel, kontrol terhadap siklus sel, dan apoptosis pada sel prostat. ${ }^{10,11}$ Hubungan ER dengan kanker prostat memang belum jelas, sementara kontroversi hubungan reseptor ini dengan kanker prostat dan prognosis kanker prostat terus berlanjut. 12

Sejauh ini belum ada penelitian yang dilakukan untuk mencari hubungan ER dengan kanker prostat di Indonesia. Oleh karena itu, dilakukan penelitian ini guna mengetahui hubungan biomarker tersebut dengan skor Gleason, derajat diferensiasi, dan prognostic grade group. 
Hasil akhir dari penelitian ini diharapkan dapat dijadikan dasar untuk menentukan prognosis pada adenokarsinoma prostat.

\section{Bahan dan Metode}

\section{Sampel Penelitian}

Sampel penelitian adalah blok parafin dari kasus adenokarsinoma prostat di Instalasi Patologi Anatomi RSUD Dr. Saiful Anwar Malang, yang didapatkan sejak tahun 2018 hingga tahun 2020 sebanyak 31 sampel. Kriteria inklusi pada penelitian ini adalah semua penderita yang telah diperiksa sediaan histopatologi hasil operasi, kerokan maupun biopsinya dan didiagnosis sebagai adenokarsinoma prostat di Laboratorium Patologi Anatomi RSUD Dr. Saiful Anwar Malang. Kriteria eksklusi adalah jika didapatkan kerusakan pada blok parafin. Kasus yang memenuhi kriteria inklusi dan ekslusi akan diambil sebagai sampel untuk mencukupi jumlah sampel minimal sesuai kebutuhan. Jadi teknik pengambilan sampel adalah teknik purposive sampling. Penelitian ini telah mendapatkan persetujuan Komisi Etik Penelitian Kesehatan RSUD Dr. Saiful Anwar dengan nomor 400/017/K.3/302/2021.

\section{Deteksi Ekspresi Estrogen Receptor} Menggunakan Metode Immunohistokimia

Selain dibuat preparat histopatologi, blok parafin juga disiapkan untuk metode immunohistokimia yaitu untuk menentukan ekspresi estrogen receptor (ER) dengan menggunakan rabbit monoclonal antibody (IgG) Sp1 anti-human estrogen receptor (Biocare Medical CRM 301 A,B,C) dengan teknik pewarnaan sesuai prosedur Biocare Medical. ${ }^{13}$ Ekspresi ER dihitung dari persentase jumlah sel epitel kelenjar prostat pada sediaan yang berwarna coklat pada inti. Hasil pulasan imunohistokimia diamati menggunakan mikroskop cahaya (Olympus tipe CX 23) dengan pembesaran 400x. Persentase dihitung dari berapa jumlah sel yang positif yang mengekspresikan ER dari 1000 sel tumor dikalikan 100\%. Seluruh preparat dibaca oleh 3 pengamat secara acak tanpa mengetahui data klinis maupun histopatologisnya (blind). ${ }^{19,20}$

\section{Penentuan Skor dan Derajat Adenokarsinoma Prostat}

Penetapan diagnosis adenokarsinoma dilakukan berdasarkan sampel adenokarsinoma prostat yang telah direview ulang oleh peneliti setelah dilakukan pemeriksaan histopatologis dengan pengecatan Hematoxyllin-Eosin. Kemudian, dilakukan penentuan skor Gleason, derajat diferensiasi, dan prognostic grade group. Derajat (grade) kanker prostat ditentukan dengan menggunakan skor Gleason yang dihitung dari jumlah skor dari 2 pola arsitektur dari tumor yang paling dominan. ${ }^{1,7}$ Pola arsitektur tumor yang primer (predominant) yang paling dominan, dan pola asitektur tumor yang sekunder (second most prevalent) yang dominan setelahnya, masing-masing diberi angka 1 hingga 5 berdasarkan 5 pola dasar pada New Modified Gleason Grading System menurut Konsensus International Society of Urological Pathology (ISUP) 2014. Lima pola dasar gambaran histopatologis menurut sistem Gleason adalah berdasarkan diferensiasi kelenjar dan pola pertumbuhan tumor pada stroma prostat. ${ }^{14,15}$ Pemeriksaan dilakukan menggunakan mikroskop pembesaran objektif $4 x$ dan $10 x$, dan bila diperlukan menggunakan pembesaran objektif 40x.1,7,16 Derajat diferensiasi adenokarsinoma prostat ditentukan berdasarkan skor Gleason, yaitu diferensiasi baik (well differentiated) untuk skor Gleason $\leq 6$, diferensiasi sedang (moderate differentiated) untuk skor Gleason 7, dan diferensasi buruk (poorly differentiated) untuk skor Gleason 8-10.17,18 Pengukuran prognosis kanker prostat menggunakan prognostic grade group (PGG) yang diadopsi oleh WHO 2016 dari Konsensus ISUP 2014.15 
Prognostic grade group pada penelitian diberi skor sesuai dengan gradenya, misal PGG 1 nilai skor 1, PGG 2 nilai skor 2 dan seterusnya untuk memudahkan analisis.

\section{Analisis Data}

Keseluruhan data dilakukan analisis statistik. Pada variabel ekspresi ER dilakukan uji normalitas dengan menggunakan ShapiroWilk karena jumlah sampel $<50$. Oleh karena sebaran data tidak normal, maka uji korelasi Spearman digunakan untuk mengetahui hubungan antara ekspresi ER dengan skor Gleason, derajat diferensiasi, dan skor PGG. ${ }^{21}$

\section{Hasil}

Karakteristik Dasar Sampel Peneltian

Rerata usia subjek penelitian pada kelompok adenokarsinoma prostat adalah $68 \pm 8$ tahun. Pada skor Gleason 7 dan 10 didapatkan sebanyak 2 sampel (6,5\%), sedangkan skor Gleason 8 dan 9 masingmasing sebanyak 13 sampel (41,9\%), dan 14 sampel $(45,2 \%)$, dan tidak didapatkan sampel pada skor Gleason $\leq 6$. Hal ini menunjukkan ketidakseimbangan jumlah sampel pada masing-masing skor Gleason. Pada derajat diferensiasi juga didapatkan perbedaan jumlah sampel yaitu 2 sampel pada moderately differentiated (6,5\%), 29 sampel pada poorly differentiated $(93,5 \%)$, dan tidak didapatkan sampel pada well differentiated. Pada prognostic grade group (PGG) terdapat perbedaan jumlah sampel, pada PGG 3 sebanyak 2 sampel (6,5\%), PGG 4 sebanyak 13 sampel $(41,9 \%)$, PGG 5 sebanyak 16 sampel $(51,6 \%)$, dan tidak didapatkan sampel pada PGG 1 dan 2. Jumlah sampel didominasi oleh PGG 5 (Tabel 1).

Korelasi Ekspresi Estrogen Receptor dengan Skor Gleason pada Adenokarsinoma Prostat Spesimen adenokarsinoma prostat yang telah dihitung ekspresi ER-nya kemudian dikelompokkan sesuai skor Gleason. Penilaian skor Gleason pada preparat histopatologi dapat dilihat pada Gambar 1 dan ekspresi ER pada masing-masing skor Gleason pada Gambar 2.

Hasil uji korelasi Spearman skor Gleason dan ekspresi reseptor estrogen pada spesimen adenokarsinoma prostat menunjukkan korelasi yang tidak bermakna $(p=$ 0,601 dan koefisien korelasi 0,098). Pada skor Gleason 7 didapatkan rata-rata ekspresi reseptor estrogen sebanyak 5,00, skor Gleason 8 didapatkan rata-rata ekspresi reseptor estrogen sebanyak 8,18 , skor Gleason 9 didapatkan rata-rata ekspresi reseptor estrogen sebanyak 9,24 dan pada skor Gleason 10 didapatkan rata-rata reseptor estrogen sebanyak 7,20 (Tabel 2).

Tabel 1. Karakteristik sampel penelitian

\begin{tabular}{lc}
\hline \multicolumn{1}{c}{ Kriteria Sampel } & Jumlah Sampel $(\mathrm{n}=31)$ \\
\hline Usia (rerata \pm SD) & $68 \pm 8$ tahun \\
Skor Gleason $(\%)$ & \\
7 & $2(6,5 \%)$ \\
8 & $13(41,9 \%)$ \\
9 & $14(45,2 \%)$ \\
10 & $2(6,5 \%)$ \\
Derajat Diferensiasi (\%) & \\
Well differentiated & 0 \\
Moderately differentiated & $2(6,5 \%)$ \\
Poorly differentiated & $29(93,5 \%)$ \\
Prognostic Grade Group (\%) & \\
3 & $2(6,5 \%)$ \\
4 & $13(41,9 \%)$ \\
5 & $16(51,6 \%)$ \\
\hline
\end{tabular}


Korelasi Ekspresi Reseptor Estrogen dengan Derajat Diferensiasi Adenokarsinoma Prostat

Pada penelitian ini didapatkan derajat diferensiasi spesimen adenokarsinoma prostat terbagi ke dalam 2 kelompok yaitu moderately differentiated dan poorly differentiated, dan tidak didapatkan kategori well differentiated adenokarsinoma prostat. Korelasi derajat diferensiasi dengan ekspresi ER pada adenokarsinoma prostat dianalisis dengan uji Spearman dan didapatkan hubungan yang tidak bermakna ( $p=0,754$ dengan koefisien korelasi 0,059 ). Selain itu, didapatkan ratarata ekspresi reseptor estrogen pada kelompok moderately differentiated adalah 5,00 , sedangkan pada kelompok poorly differentiated adalah 8,62 (Tabel 3).
Korelasi Ekspresi Reseptor Estrogen dengan Prognostic Grade Group pada Adenokarsinoma Prostat

Uji korelasi prognostic grade group dengan ekspresi ER pada adenokarsinoma dilakukan dengan uji Spearman, yang mendapatkan nilai $p=0,596$, dengan koefisien korelasi 0,099 . Maka, disimpulkan korelasi prognostic grade group dan ekspresi ER tidak bermakna. Kemudian, didapatkan rata-rata ekspresi ER pada prognostic grade group 3 sebanyak 5,00 , prognostic grade group 4 didapatkan rata-rata ekspresi reseptor estrogen sebanyak 8,18 , dan pada prognostic grade group 5 didapatkan rata-rata reseptor estrogen sebanyak 8,98 (Tabel 4).

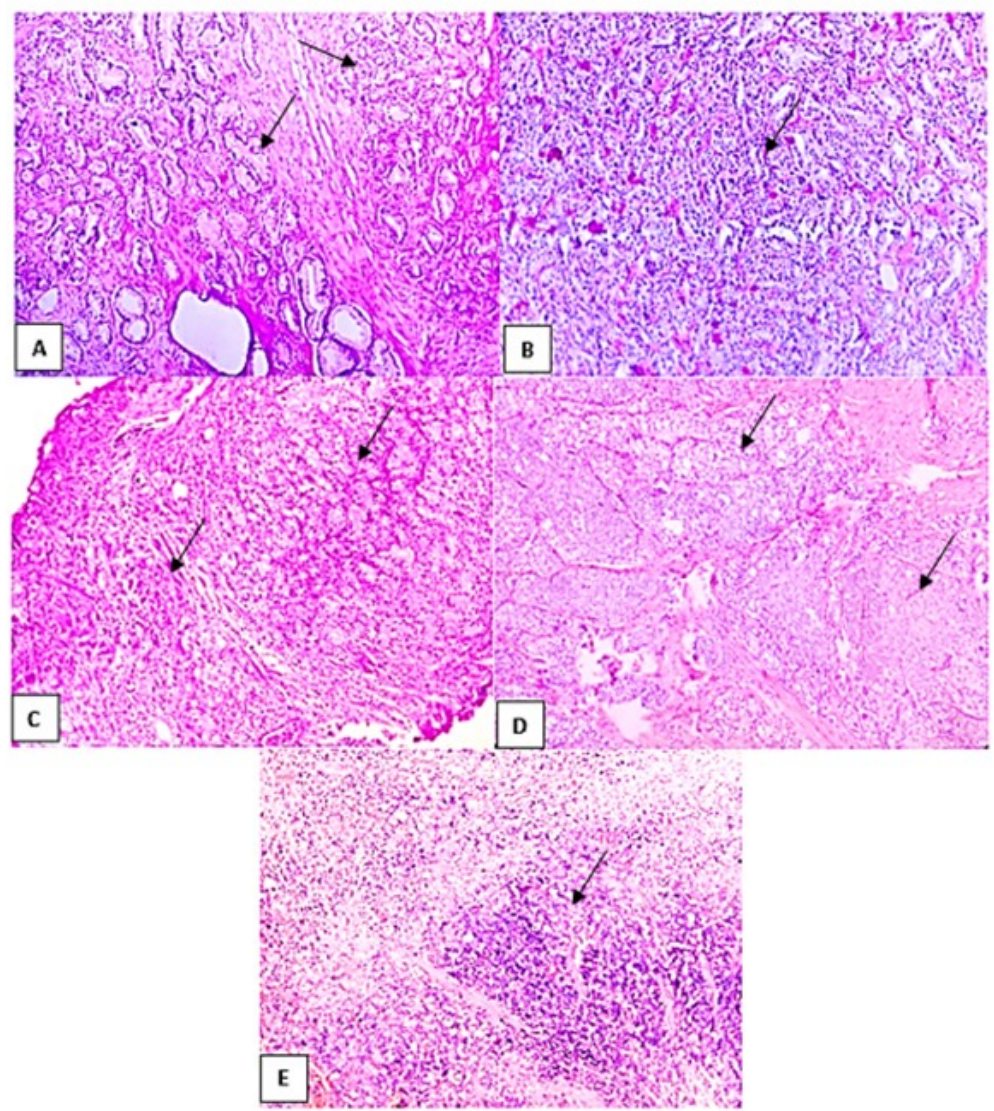

Gambar 1. Gambaran histopatologi adenokarsinoma prostat (tanda panah hitam) (HE, 100x)

Keterangan: A. Histopatologi adenokarsinoma prostat skor Gleason 4+3, terdiri atas struktur fused gland dan well formed gland B. Histopatologi adenokarsinoma prostat skor Gleason 4+4, terdiri atas kelenjar bentuk kribriformis. C. Histopatologi adenokarsinoma prostat skor Gleason 4+5, didominasi oleh kelenjar yang kribriformis dan single cell. D. Histopatologi adenokarsinoma prostat skor Gleason 5+4, didominasi oleh single cell, kemudian diikuti oleh kelenjar yang kribriformis. E. Histopatologi adenokarsinoma prostat skor Gleason 5+5, didominasi oleh single cell dengan struktur solid. 


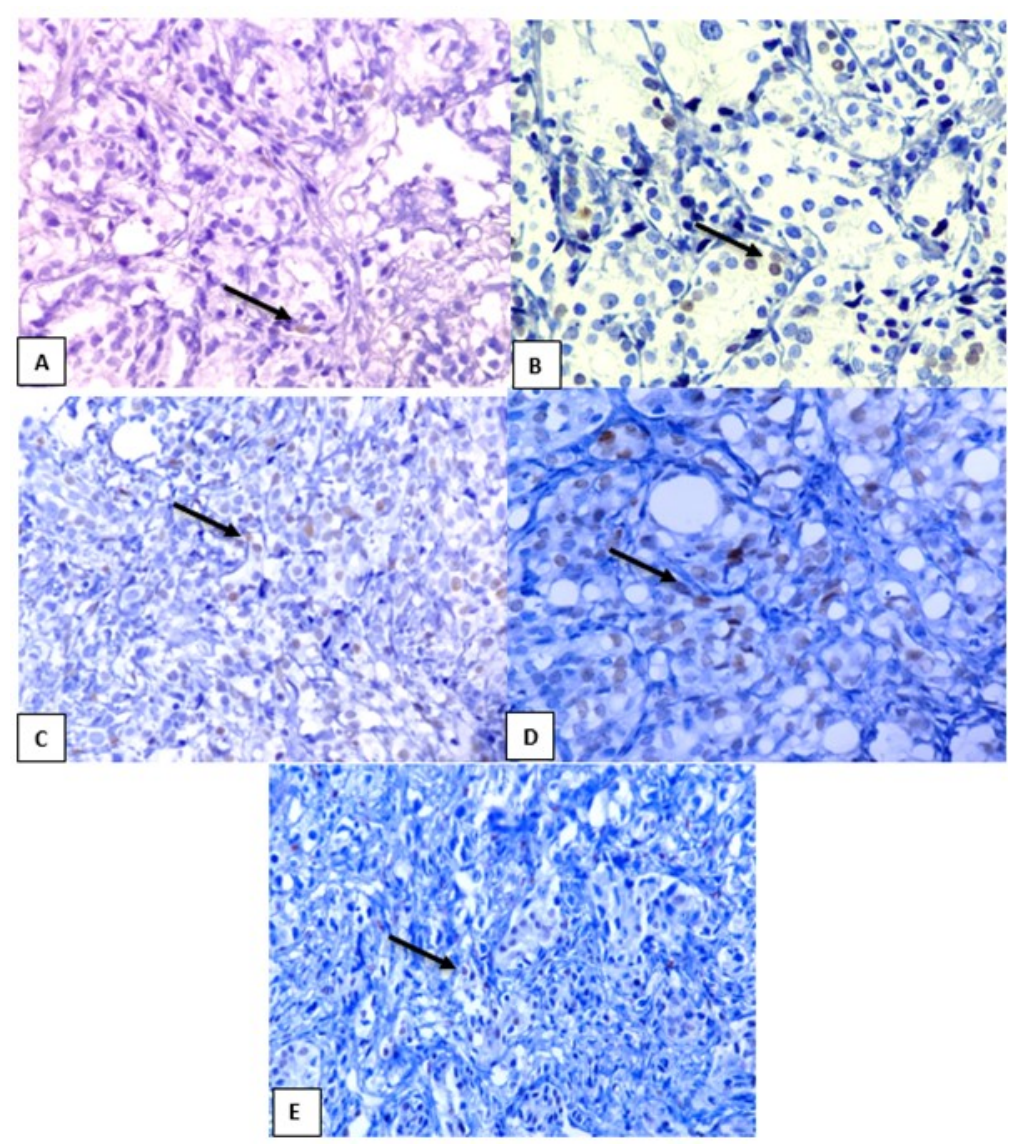

Gambar 2. Ekspresi estrogen reseptor pada spesimen adenokarsinoma prostat pada masingmasing kelompok skor Gleason (tanda panah hitam) (HE, 400x)

Keterangan: A. Ekspresi ER pada skor Gleason 4+3, B. Ekspresi ER pada skor Gleason 4+4, C. Ekspresi ER pada skor Gleason GS 4+5, D. Ekspresi ER pada skor Gleason 5+4, E. Ekspresi ER pada skor Gleason $5+5$

Tabel 2. Rerata ekspresi estrogen reseptor terhadap skor Gleason

\begin{tabular}{cc}
\hline Skor Gleason & Ekspresi ER(\%) \\
\hline$<6$ & - \\
7 & 5,00 \\
8 & 8,18 \\
9 & 9,24 \\
10 & 7,20 \\
\hline
\end{tabular}

Tabel 3. Rerata ekspresi ER terhadap derajat diferensiasi

\begin{tabular}{lc}
\hline \multicolumn{1}{c}{ Derajat Diferensiasi } & Ekspresi $\mathrm{ER}(\%)$ \\
\hline Well differentiated & - \\
Moderately differentiated & 5,00 \\
Poorly differentiated & 8,62 \\
\hline
\end{tabular}


Tabel 4. Rerata ekspresi ER terhadap prognostic grade group

\begin{tabular}{cc}
\hline Prognostic Grade Group & Ekspresi ER(\%) \\
\hline 1 & - \\
2 & - \\
3 & 5,00 \\
4 & 8,18 \\
\hline
\end{tabular}

\section{Pembahasan}

\section{Karakteristik Sampel Penelitian}

Pada penelitian ini didapatkan rata-rata usia sampel adenokarsinoma prostat adalah 68 tahun. Hal ini sesuai dengan hasil penelitian sebelumnya bahwa insiden adenokarsinoma prostat banyak didapatkan pada usia tua. ${ }^{1}$ Selain itu, juga didapatkan perbedaan jumlah sampel pada masingmasing kelompok berdasarkan skor Gleason, derajat diferensiasi dan prognostic grade group (PGG) (Tabel 1). Hal ini sesuai dengan penelitian sebelumnya bahwa adenokarsinoma prostat lebih sering didapatkan pada zona perifer prostat, sehingga seringkali tidak bisa terdiagnosis pada stadium dini atau grade awal.4,22 Hasil pemeriksaan patologi anatomi spesimen adenokarsinoma prostat banyak didapatkan pasien dengan grade keganasan yang tinggi, karena kecil kemungkinan pasien memeriksakan diri pada saat derajat keganasan masih rendah, sehingga tidak didapatkan jumlah sampel yang seimbang.

Korelasi Ekspresi Estrogen Receptor dengan Skor Gleason pada Adenokarsinoma Prostat

Korelasi skor Gleason dan ekspresi ER pada spesimen adenokarsinoma prostat menunjukkan korelasi yang tidak bermakna ( $p$ $=0,601)$. Hasil penelitian sebelumnya juga menyebutkan tidak ada hubungan antara ekspresi ER $\beta$ dengan skor Gleason pada kanker prostat.23,24,25,26 Berbeda dengan penelitian tersebut yang menggunakan $E R \beta$, pada penelitian ini menggunakan marker ERa dan ERß. Namun, pada penelitian ini ekspresi ER banyak ditunjukkan pada sel epithel yang mengekspresikan ER $\beta$, dibandingkan pada stroma yang mengekspresikan ERa.

Penelitian azizan et al (2018) menyebutkan bahwa kasus-kasus dengan indeks proliferasi yang tinggi mengekspresikan ERß. Pada beberapa kasus menunjukkan bahwa ER $\beta$ diekspresikan dalam sel individu (single cell) yang merupakan penanda proliferasi. ER $\beta$ beralih peran selama perkembangan kanker. Di awal fase perkembangan kanker prostat, ER $\beta$ muncul sebagai supresor tumor dan kemudian menjadi promotor tumor ketika sel kanker mengalami perkembangan. ${ }^{9}$ Selain itu, ada berbagai isoform ER $\beta$ yang memiliki fungsi penekan tumor atau promosi tumor. ${ }^{27}$ ERa yang terdapat pada stroma dikaitkan dengan proliferasi dan transkripsi sel dan memiliki peran yang berlawanan dengan ERß. ${ }^{11}$

Adanya perubahan peran ER $\beta$ yang awalnya sebagai supresor tumor, kemudian dalam perkembangannya berubah menjadi promotor tumor dapat disebabkan karena berbagai isoform ER $\beta$ yang memiliki fungsi penekan tumor atau promosi tumor. Hal ini menjelaskan mengapa tidak terdapat hubungan yang bermakna antara skor Gleason dengan ekspresi ER. ${ }^{9,27}$ Selain itu, didapatkan keterlibatan ERa yang meskipun tidak dominan terekspresi, tapi masih mungkin didapatkan pada stroma tumor, yang diketahui memiliki peran yang berlawanan dengan ERß. ${ }^{11}$ 
Maka, alasan ini yang menyebabkan tidak terdapat hubungan bermakna antara skor Gleason dengan ekspresi ER.

Korelasi Ekspresi Reseptor Estrogen dengan Derajat Diferensiasi Adenokarsinoma Prostat

Dari temuan skor Gleason tersebut dilakukan klasifikasi lanjutan untuk menentukan derajat diferensiasi. Meskipun didapatkan rata-rata ekspresi reseptor estrogen pada kelompok poorly differentiated adenokarsinoma prostat lebih tinggi dibandingkan kelompok moderately differentiated, namun hal ini menunjukkan korelasi yang tidak bermakna antara derajat diferensiasi pada spesimen adenokarsinoma prostat dengan ekspresi ER $(p=0,754)$. Hal ini berbeda dengan penelitian yang dilakukan oleh Gabal et al (2007) dan Nisid et al (2017) yang menyebutkan bahwa ekspresi ERß berbanding terbalik dengan derajat diferensiasi dengan kanker prostat. ${ }^{28,29}$ Penelitian terbaru pada manusia Hammes et al. (2019) menunjukkan bahwa ekspresi ERß yang tinggi terjadi pada banyak kanker prostat dan berkorelasi dengan prognosis yang baik. ${ }^{28}$ Derajat diferensiasi ditentukan berdasarkan skor Gleason, maka seperti halnya skor Gleason, perubahan peran dan bervariasinya fungsi $E R \beta$, serta keterlibatan ERa menjelaskan mengapa tidak terdapat hubungan yang bermakna pada ekspresi ER dan derajat diferensiasi.9,11

Korelasi Ekspresi Reseptor Estrogen dengan Prognostic Grade Group pada Adenokarsinoma Prostat

Uji korelasi ekspresi reseptor estrogen dengan prognostic grade group pada kelompok adenokarsinoma prostat menunjukkan korelasi yang tidak bermakna $(p=$ 0,596). Walaupun terdapat kecenderungan peningkatan rata-rata ekspresi ER pada PGG yang lebih tinggi. Penilaian prognostic grade group (PGG) juga didasarkan pada skor Gleason. maka seperti halnya skor Gleason, perubahan peran dan bervariasinya fungsi $E R \beta$, serta keterlibatan ERa merupakan alasan tidak terdapat hubungan yang bermakna antara ekspresi ER pada prognostic grade group. 9,11

Penelitian ini memiliki keterbatasan yaitu menggunakan biomarker yang tidak spesifik. Biomarker tersebut digunakan secara rutin dalam pemeriksaan immunohistokimia untuk kanker payudara. Selain itu, penelitian ini merupakan penelitian yang belum pernah dilakukan di Indonesia, sehingga diharapkan dapat digunakan sebagai informasi marker diagnostik maupun prognostik baru dalam perkembangan tatalaksana adenokarsinoma prostat. Perlu dilakukan penelitian yang mempertimbangkan keterbatasan pada penelitian ini, termasuk menggunakan biomarker yang spesifik yang memisahkan ERa dan ERß untuk mendapatkan hasil penelitian yang diharapkan memiliki korelasi bermakna.

\section{Kesimpulan}

Hasil penelitian ini menyimpulkan bahwa tidak didapatkan korelasi yang bermakna antara ekspresi reseptor estrogen dengan skor Gleason, derajat diferensiasi, dan prognostic grade group adenokarsinoma prostat. Maka, disarankan untuk menentukan prognosis kanker prostat dari berbagai aspek, tidak hanya dari skor Gleason, derajat diferensiasi, dan prognostic grade group, tetapi juga mempertimbangkan stadium TNM dan kadar prostate spesific antigen (PSA).

\section{Daftar Pustaka}

1. Humphrey PA, Amin MB, Berney DM, Billis A, Cao D, Cheng L, et.al. Acinar Adenocarcinoma. Dalam: Moch $\mathrm{H}$, Humphrey PA, Ubright TM, Reuter VE, (Editors). World Health Organization Classification of Tumours of The Urinary System and Male Genital Organs. Lyon: IARC Press. 2016. P. 138-162. 
2. GLOBOCAN. 2018. International Agency for Research on Cancer WHO [Internet]. 2018 September [cited 2018 Sept 30]. Available from: https://gco.iarc.fr/today/ data/factsheets/populations/900-world-factsheets.pdf

3. Badan Penelitian dan Pengembangan Kesehatan Republik Indonesia (Balitbangkes RI). Buku 2: Riskesdas 2013 dalam Angka. Jakarta: Litbangkes Kemenkes RI. 2013. HIm. 144.

4. Komite Penanggulangan Kanker Nasional (KPKN). Pedoman Nasional Pelayanan Kedokteran: Kanker Prostat. Kementerian Kesehatan Republik Indonesia. Jakarta: Kementerian Kesehatan Republik Indonesia. 2017. HIm. 6-94.

5. Badan Registrasi Kanker Perhimpunan Dokter Spesialis Patologi Indonesia. Kanker di Indonesia Tahun 2014 Data Histopatologik. Jakarta: Yayasan Kanker Indonesia. 2018.

6. Umbas R, Muchtar C, Hamid R. Terapi Radikal pada Penderita Kanker Prostat: Tindak Lanjut Jangka Panjang dan Faktor Prediksi Survival. Dalam: Komite Penanggulangan Kanker Nasional. Pedoman Nasional Pelayanan Kedokteran: Kanker Prostat. Kementerian Kesehatan Republik Indonesia. Jakarta: Kemenkes RI. 2017. HIm. 6-94.

7. Humphrey PA. Histopathology of Prostate Cancer. Cold Spring Harb Perspect Med. 2017: 7: a030411.

8. Grindstad T, Skjefstad K, Andersen S, Ness $N$, Nordby $Y$, Al-Saad $S$, et al. Estrogen Receptors $a$ and $\beta$ and Aromatase as Independent Predictors for Prostate Cancer Outcome. Scientific Reports. 2016; 6:33114. DOI: 10.1038/ srep33114.

9. Azizan N, Hiyati F, Tizen NMS, Farouk WI, Masir N. Role of Co-Expression of Estrogen Receptor Beta and Ki67 in Prostate Adenocarcinoma. Investig Clin Urol. 2018; 59:232-237.
10.Hua $H$, Zhang $H$, Kong $Q$, dan Jiang $Y$. Mechanisms for Estrogen Receptor Expression in Human Cancer. Exp Hematol Oncol. 2018; 7:24. doi: 10.1186/s40164018-0116-7.

11. Kowalska $\mathrm{K}$ dan Ciesielka AWP. Oestrogens and Oestrogen Receptors in Prostate Cancer. SpringerPlus. 2016; 5 (522): 1-9.

12. Christoforou $P$, Christopoulus $P F$, dan Koutsilieris M. The Role of Estrogen Receptor $\beta$ in Prostate Cancer. Mol Med. 2014; 20:427-434.

13. Biocare Medical. Estrogen Receptor (ER) [SP1]: Concentrated and Prediluted Rabbit Monoclonal Antibody. Pacheco: Biocare Medical. 2020.

14. Gordetsky J, Epstein J. Grading of Prostatic Adenocarcinoma: Current State and Prognostic Implications. Diagnostik Pathology 2016.11(25):1-8.

15. Rao V, Garudadri G, Shilpa AS, Fonseca $D$, Sudha SM, Sharma R, et al. Validation of the WHO 2016 New Gleason Score of Prostatic Carcinoma. Urology Annals. 2018; 10(3):324-329.

16. Barakzai MA. Prostatic Adenocarcinoma: A grading from Gleason to the New Grade -Group System: A Historical and Critical Review. Asian Pac J Cancer Prev. 2019; 20(3):661-666.

17. Epstein J. An Update of the Gleason Grading System. J Urol. 2010;183(2):43340. doi: 10.1016/j.juro.2009.10.046.

18. Osorio CFEM, Costa WS, Gallo CBM, Sampaio FJB. Expression of Stromal Elements of Prostatic Adenocarcinoma in Different Gleason Scores. Acta Cir Bras. 2019; 34(10): e201901005.

19. Allison KHM, Elizabeth $H$, Hammond MEH, Mitchell Dowsett M, et al. Estrogen and Progesterone Receptor Testing in Breast Cancer: ASCO/CAP Guideline Update. Journal of Clinical Oncology. 2020; 38(12):1346-1366. 
20.Ahlin C, Lundgren C, Embretsén-Varro E. et al. High Expression of Cyclin D1 is Associated to High Proliferation Rate and Increased Risk of Mortality in Women with ER-Positive but not in ER-Negative Breast Cancers. Breast Cancer Res Treat. 2017; 164:667-678.

21. Sastroasmoro S, Ismael S. Dasar-Dasar Metodologi Penelitian Klinis. Edisi keempat. Jakarta: Sagung Seto. 2011. HIm. 358-366.

22. Kristiani E, Tanurahardja B. Aspek Histopatologik Adenokarsinoma Prostat. Mediciunus. 2016; 5(2):6-13.

23. Fixemer $\mathrm{T}$, Remberger $\mathrm{K}$, Bonkhoff $\mathrm{H}$. Differential Expression of the Estrogen Receptor Beta (ERbeta) in Human Prostate Tissue, Premalignant Chages, and in Primary, Metastatic, and Recurrent Prostatic Adenocarcinoma. Prostate. 2003; 54(2):79-87.

24. Al-Maghribi JA, Hassan TM, dan AbdelMeguid TA. Expression of Alpha and Beta Receptors in Prostate Cancer and Hyperplasia: Immunohhistochemical Analysis. African Journal of Urology. 2010; 16(3):79-87.

25. Grover SK, Agarwal S, Gupta S, Wadhwa
$\mathrm{N}$, dan Sharma N. Expression of Estrogen Receptor ßand KI 67 in Benign \& Malignant Human Prostate Lesions by Immunohistochemistry. Pathol.Oncol.Res. 2015; 21:651-657.

26. Bera KN, Yadav SK, Prakash O, Singh S, Sarin N. Immunoexpression of Estrogen Receptor- $\beta$ and Progesterone Receptor in Prostate Adenocarcinoma, Does It Inhibit Neoplastic Proliferation and Invasion?. Indian J Pathol Microbiol. 2020; 63:30-33.

27. Hammes SR, Levin ER. Impact of Estrogens in Males and Androgens in Females. J Clin Invest. 2019; 129(5):18181826. DOI:10.1172/JCl125755.

28. Gabal SM, Habib FM, Helmy DO, dan Ibrahim MF. Expression of Estrogen Receptor-B (ER-B) in Benign and Malignant Prostatic Epithelial Cells and Its Correlation with the Clinic-Pathological Features. J Egypt Natl Canc Inst. 2007; 19 (4):239-48.

29. Nishit, Prasad CSBR, Raj SBV. Expression of Beta Estrogen Receptor in Benign Prostatic Hyperplasia and Adenocarcinoma of Prostate. International Journal of Recent Scientific Research. 2017; 8(3):15843-7. 